\title{
Climate change, ecosystem services and migration in the Marshall Islands: are they related?
}

\author{
Kees van der Geest ${ }^{1}$ (D) Maxine Burkett ${ }^{2} \cdot$ Juno Fitzpatrick $^{2} \cdot$ Mark Stege $^{3}$. \\ Brittany Wheeler ${ }^{4}$
}

Received: 8 August 2019 / Accepted: 22 December 2019/ Published online: 10 April 2020

(C) The Author(s) 2020

\begin{abstract}
As one of the lowest-lying island nation states in the world, the Republic of the Marshall Islands is vulnerable to sea level rise, flooding and the associated impacts on soil and water salinity. Persistent drought is further affecting agricultural production and access to drinking water, and heat stress is increasingly common. The number of Marshallese people residing in the USA has increased rapidly from 6650 in 2000 to an estimated 30,000 in 2018. While we know that climate change is already affecting the Marshall Islands and that there are significant migration flows, we do not know to what extent people already migrate because of climate change. This paper addresses this gap and presents findings from interdisciplinary fieldwork in the Marshall Islands and destination areas in the USA. The research team conducted a survey $(N=278)$, focus group discussions, expert interviews and a geo-spatial analysis of flood extent and migration rates to study the relationship between climatic events, ecosystem services and migration. The results show that respondents primarily cite education, health care, work and family visits as migration drivers, and only few mention climate impacts or environmental change. However, respondents do identify impacts of climate change on their livelihoods, health and safety, and the study finds significant correlations between climate impacts, trends in ecosystem services and migration propensities at household level. Furthermore, 62\% of Marshallese respondents in the USA indicated that climate change affects their decision to return to Marshall Islands in the future.
\end{abstract}

Kees van der Geest

geest@ehs.unu.edu

1 United Nations University Institute for Environment and Human Security, Bonn, Germany

2 University of Hawaii at Mānoa, Honolulu, HI, USA

3 Marshall Islands Conservation Society, Majuro, Marshall Islands

4 Clark University, Worcester, MA, USA 
Keywords Climate change $\cdot$ Migration $\cdot$ Ecosystem services $\cdot$ Sea level rise $\cdot$ Drought $\cdot$ Pacific

\section{Introduction}

Due to their small size and low elevation, Pacific Islands face considerable risk of inundation, coastal erosion and loss of territory when sea levels rise due to global warming and natural variability (Nurse et al. 2014). Media outlets frequently speak of the 'sinking islands' of the pacific $^{1}$ and portray their inhabitants as "climate refugees". 2 The science is more nuanced about the future of the Pacific Islands and the need to relocate. Some research confirms the sinking island narrative, with the important correction that islands become uninhabitable due to salinity intrusion long before they disappear under water (Storlazzi et al. 2018). Other research emphasises uncertainty in projections and adaptive capacity of human and natural systems (Barnett 2017; Kench et al. 2018).

The Republic of the Marshall Islands (RMI) is a nation of widely dispersed, low-lying coral atolls and islands, with approximately 70 miles $^{2}$ of land area scattered across 750,000 miles $^{2}$ of ocean (Bureau of East Asian and Pacific Affairs 2015). The Marshall Islands consist of 29 coral atolls and 5 raised coral islands. Average elevation for the RMI is approximately $2 \mathrm{~m}$ above mean sea level (Owen et al. 2016).

As one of the lowest-lying island nation states in the world, the RMI is acutely vulnerable to sea level rise, flooding and the associated intrusion of saltwater into crucial freshwater supplies. Persistent drought is further affecting agricultural production and access to drinking water. Many Marshallese communities are already experiencing these changes that affect the habitability of their islands (Keener et al. 2012; Marra et al. 2017).

Within the Marshall Islands, there are substantial migration flows between islands, particularly from outer islands to the capital Majuro. In 2011, more than half $(52.3 \%)$ the population of the RMI resided on Majuro, against only $24.1 \%$ at the time of the first population census (in 1958). Besides internal migration, many Marshallese are migrating internationally, particularly to the USA. The number of Marshallese residing in the USA has risen rapidly, from 6650 in the year 2000 to 22,434 in 2010 (US Census Bureau 2001: 9; US Census Bureau 2012: 14). ${ }^{3}$ To compare, the total population residing in the RMI was 53,158 at the time of the last population census in 2011 (Republic of the Marshall Islands 2012: 13). Currently, it is estimated that approximately 30,000 Marshallese reside in the USA (Van der Geest et al. 2019a). There is a bilateral agreement between the Republic of the Marshall Islands and the USA - the Compact of Free Association - that allows Marshallese people to live and work in the USA without a visa (McElfish 2016). The current agreement expires in 2023, and it is expected that migration to the USA will increase in the years before (Morris et al. 2019), as it did prior to the previous amendment in 2003 (Graham 2008).

\footnotetext{
${ }^{1}$ See for instance: https://www.nytimes.com/2018/01/24/opinion/kiribati-climate-change.html; https:/www. theguardian.com/guardianweekly/story/0,12674,1108791,00.html

${ }^{2}$ See for instance: https://www.theguardian.com/environment/2017/apr/05/disaster-alley-australia-could-be-setto-receive-new-wave-of-climate-refugees; https:/www.nytimes.com/tbooks/book/climate-refugees-how-globalchange-is-displacing-millions/format/pdf/

${ }^{3}$ The source for the total Marshallese population in the USA in 2000 is US Census Bureau (2001: 9). The source for the total Marshallese population in the USA in 2010 is the 2010 Census Summary File 2, Profile of General Population and Housing Characteristics: 2010.
} 
While existing research shows that climate change is already affecting the Marshall Islands (Marra et al. 2017) and population censuses show that there are significant migration flows, it is not clear to what extent Marshallese people are already migrating because of climate change and its impact on ecosystem services and livelihoods, which is the topic of this article. Ecosystem services can be defined as the benefits that people obtain from the natural environment (MEA (Millennium Ecosystem Assessment) 2005). Central to the research is the notion that people do not migrate because of climate change as such, but because of the way climate change affects their livelihoods, food security and well-being (Afifi et al. 2016). This is shown schematically in the conceptual framework in Fig. 1. The framework further acknowledges that impacts of climate change on people are often caused by climate impacts on ecosystems and the services they provide (Black et al. 2011; Foresight 2011; Zommers et al. 2016). Hence, the question this article attempts to answer is as follows: 'To what extent are climatic stressors and their impacts on ecosystems, livelihoods and habitability, driving migration in the Marshall Islands?'

A recent review of the academic literature on migration and environmental change revealed four key findings (Milan 2016). First, due to climate change, it is expected that the impact of environmental change on migration will be stronger in the future than it is today. Second, most environmentally induced migration will be within state borders and relatively short distance, rather than international. Notable exceptions are border areas and small states, particularly small island developing states. Third, migration is often seen as a failure to adapt to environmental changes, but more and more studies emphasise that migration can also be part of successful household strategies to diversify livelihoods and reduce risk (McLeman and Smit 2006; Oakes et al. 2019). A last finding from the literature review is that climate change will not only force millions of people to migrate; a similar number of people will be trapped in vulnerable environments from where they cannot leave because they lack the means to migrate (Milan 2016).

Several studies have investigated the link between climate change and migration on Pacific Islands in the past decade. Results are mixed. Mortreux and Barnett (2009) found in Funafuti (Tuvalu) that respondents hardly cite climate as reason to migrate, and they criticise outsiders' view of migration as adaptation because it involves much cultural loss. Similarly, research from Vanuatu reveals a strong reluctance to resettle and a prioritisation of in situ adaptation measures (Perumal 2018). In a study of Kiribati, Allgood and McNamara (2017) found that climate-induced migration and displacement was already common. The Pacific Climate Change and Migration (PCCM) project included fieldwork in Tuvalu, Kiribati and Nauru. These studies find that social and economic factors are currently more important drivers of migration, but that climate impacts can be tipping points in migration decisions (Campbell et al. 2016; Milan et al. 2016; Oakes et al. 2016; Oakes 2019).

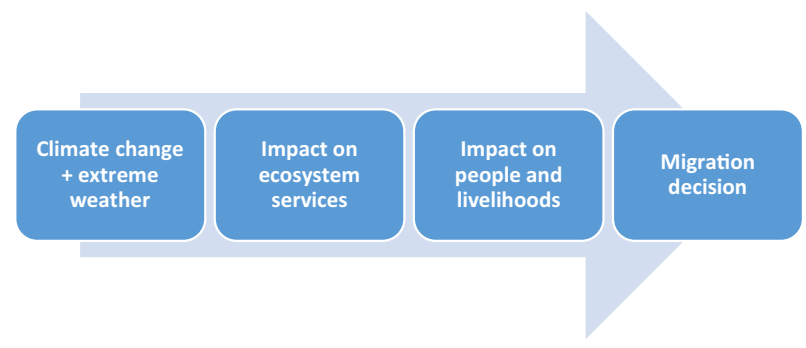

Fig. 1 The climate migration impact chain 
The present study on the Marshall Islands aims to contribute to the emerging literature on the relation between climate and migration in the Pacific and beyond.

\section{Material and methods}

To study whether climatic stressors are a driver of Marshallese migration, fieldwork was conducted in the Marshall Islands, Hawaii, Oregon and Washington. Fieldwork in the RMI took place in the spring of 2017, totaling 6 weeks. The team of two senior researchers and five research assistants spent almost 4 weeks on Majuro and 16 days on two outer islands: Mejit and Maloelap. The fieldwork among Marshallese migrants in the USA took place in the summer (Hawaii) and autumn (Oregon and Washington) of 2017 and lasted 3 weeks each.

The main data source for this article is the household questionnaire. The team interviewed a total of 278 respondents, of which 199 were in the Marshall Islands and 79 were in the USA. The questionnaire had 13 pages and the interviews took approximately 1 hour each. The questionnaire comprised mainly closed-ended questions generating quantitative information, and also some open-ended questions that generated qualitative information. The questionnaire included sections with questions about basic socio-demographic characteristics, impacts of climatic events, trends in ecosystem services, migration and adaptation policy. For each interviewed household in the RMI, the GPS location was recorded, which enabled a spatial analysis of the questionnaire data. In addition to the questionnaire, the team conducted focus group discussions and expert interviews.

Central to the design methods of this research is the acknowledgement of complexity and multi-causality in migration decisions. To unravel these complexities requires multi-level research, involving different perspectives, data types and scales (Piguet 2010; Eklund et al. 2016; van der Land et al. 2018). Therefore, the team approached the question whether climate impacts on livelihoods and ecosystems drive migration in the RMI in three different ways:

- First, by asking people why they migrated;

- Second, by exploring correlations between climate impacts on respondents' households and their migration propensities;

- Third, through spatial correlation of migration rates and environmental data, in particular flood extent.

\subsection{Site selection and sampling methods}

In the RMI, the team surveyed three study sites: Majuro, Mejit and Maloelap (see Fig. 2). Sampling of households within the study sites was random and the selection of three study sites was purposive. The team wanted to include one urban island (Majuro) and two rural outer islands. The two outer islands were selected based on several criteria. First, together they represent an important difference between an atoll (Maloelap) and a raised coral island (Mejit), of which the RMI has 29 and 5, respectively. This distinction was deemed important for understanding potential variability of climate impacts between two geologically different island formations. Through the Marshallese partner organization in the project, the team had well-established contacts in these study sites and a high level of trust, which is of crucial importance for conducting research in the Pacific where climate migration currently is a sensitive topic (Allgood and McNamara 2017; Barnett 2017). 

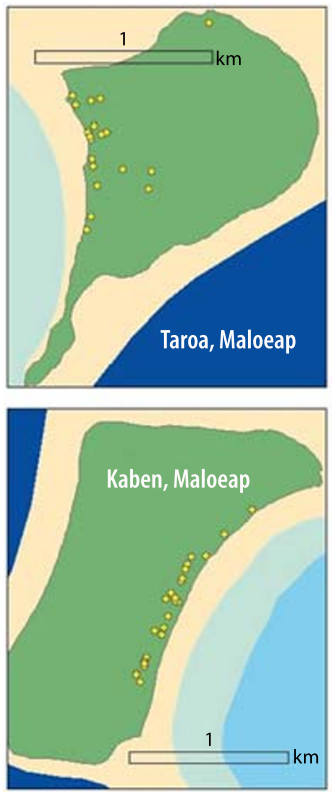

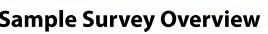

Surveyed Households (199)

Marshall Islands Climate \& Migration Project

Data sources: MICS, UH ELP

Projected Coordinate System: WGS_1984_UTM_Zone_59N Projection: Transverse Mercator

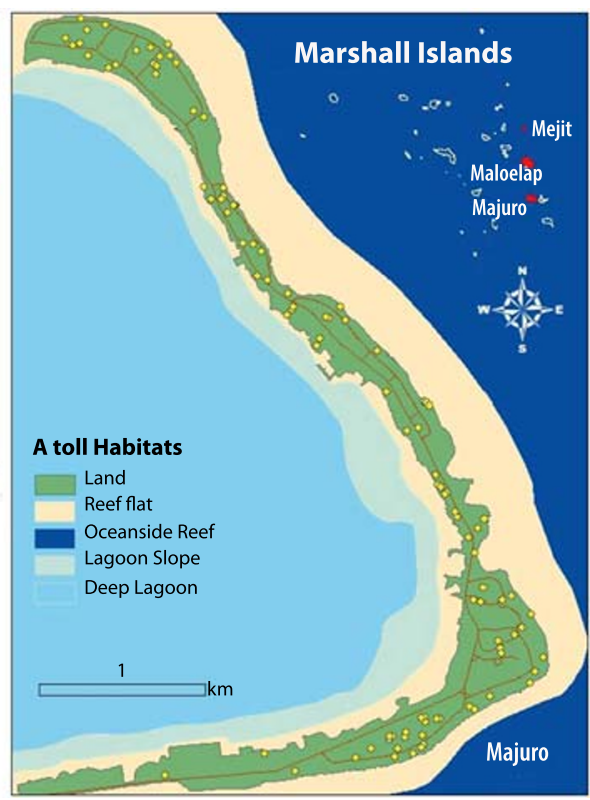

Fig. 2 The study sites in the RMI, showing GPS locations of surveyed households

On Majuro, the household selection involved two steps. First, the team decided to focus the survey on the eastern side of the atoll, where most people live and which is most exposed to inundation (Davis 2014). This included the villages of Rita, Jenrok, Uliga, Small Island and Delap. In this zone, 100 households were selected randomly from a list of 2398 households $(4.2 \%)$ that was available from the census bureau. For Mejit and Maloelap, the research team consulted census data prior to the fieldwork to have an estimate of the number of households per island. These study sites had a much smaller population (350 to 700 inhabitants), so the team decided to interview all available households on the island of Mejit and on two of the five inhabited islands of Maloelap Atoll.

In the USA, the team surveyed a total of 79 households. The study sites investigated in the USA were Hawaii (July-August 2017), Oregon and Washington (October-November 2017). The team selected these states because they were popular destinations for Marshallese migrants at the time of the 2010 US Census (US Census Bureau 2012). Within these states, the study sites were selected based on the presence of Marshallese diaspora organizations that could facilitate introductions to the communities. The snowball method was used to select respondents in these study sites.

\section{Results}

This section first describes the study population and then presents findings on how respondents perceive the changes in climate and ecosystem services and how this affects them. After that, the findings on migration patterns and drivers are presented. The focus here is on disentangling to what extent impacts of climatic events and changes in ecosystem services drive migration in the Marshall Islands. ${ }^{4}$

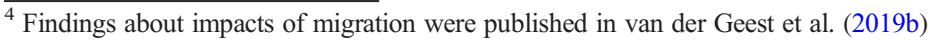




\subsection{Study population}

Table 1 shows selected socio-demographic characteristics, such as age, gender, dependency ratios, education level, income and migration status of the respondents we interviewed in the three study sites in the RMI. In the capital Majuro, respondents were a bit younger on average and more often women. Respondents on Majuro also had higher levels of formal education than on the two outer islands. Household sizes on Majuro were also higher, which is probably due to young relatives from outer islands coming to study on the main island.

An important difference between Mejit and the other two study sites was the high dependency ratio (the number of children and elderly per adult aged 19 to 64). High dependency ratios are typical for places with high out-migration rates because migration propensities are usually higher among adults than among children and the elderly (Connell 2005). In Maloelap Atoll, the dependency ratio was substantially lower than in the other two sites. This is an indication that migration rates are lower in Maloelap.

The survey found large differences in the sources of income between Majuro and the two outer islands. Agriculture, fishing and copra (dried coconut kernel) production are the main sources of income on Mejit and Maloelap. By contrast, on Majuro, private sector employment and government salaries are the most common income sources. Estimated household incomes were significantly higher on Majuro than on the outer islands. On Mejit, none of the surveyed households had an annual income of more than $\$ 5000$ and on Maloelap only $8 \%$ did. By contrast, $71 \%$ of respondents on Majuro had an annual income of more than $\$ 5000$. The outer island economies are much less centred on cash income and more on subsistence. A large proportion of the food that people on Mejit and Maloelap consume is gathered or produced locally.

Table 1 also summarizes the migration experiences of respondents in the three study sites. It distinguishes between people who have never left their island, those who moved for periods of

Table 1 Socio-demographic profile of the 3 study sites

\begin{tabular}{|c|c|c|c|c|}
\hline & Mejit & Maloelap & Majuro & Total \\
\hline Households interviewed & 50 & 50 & 99 & 199 \\
\hline Female respondents & $32 \%$ & $26 \%$ & $35 \%$ & $32 \%$ \\
\hline Mean age of respondent & 42 & 40 & 38 & 40 \\
\hline Household size & 5.9 & 6.1 & 7.2 & 6.6 \\
\hline Dependency ratio & 1.38 & 1.05 & 1.19 & 1.20 \\
\hline Elderly dependency & 0.15 & 0.07 & 0.10 & 0.10 \\
\hline Child dependency & 1.24 & 0.99 & 1.09 & 1.10 \\
\hline \multicolumn{5}{|l|}{ Education level of respondent } \\
\hline Primary school or less & $18 \%$ & $16 \%$ & $11 \%$ & $14 \%$ \\
\hline High school & $74 \%$ & $60 \%$ & $53 \%$ & $60 \%$ \\
\hline College or university & $8 \%$ & $24 \%$ & $37 \%$ & $26 \%$ \\
\hline \multicolumn{5}{|l|}{ Annual household income } \\
\hline Less than $\$ 2000$ & $86 \%$ & $57 \%$ & $21 \%$ & $49 \%$ \\
\hline$\$ 2000-\$ 5000$ & $14 \%$ & $35 \%$ & $8 \%$ & $17 \%$ \\
\hline More than $\$ 5000$ & $0 \%$ & $8 \%$ & $71 \%$ & $34 \%$ \\
\hline \multicolumn{5}{|l|}{ Respondent's migration status } \\
\hline Never left the atoll/island & $8 \%$ & $18 \%$ & $23 \%$ & $18 \%$ \\
\hline Only short migration (<1 year) & $38 \%$ & $31 \%$ & $28 \%$ & $31 \%$ \\
\hline Also long-term, but only with the RMI & $42 \%$ & $49 \%$ & $31 \%$ & $38 \%$ \\
\hline \multirow[t]{2}{*}{ Long-term, including abroad } & $12 \%$ & $2 \%$ & $19 \%$ & $13 \%$ \\
\hline & $100 \%$ & $100 \%$ & $100 \%$ & $100 \%$ \\
\hline
\end{tabular}


less than a year and those who moved for periods of more than a year. Within the last group, the table distinguishes people who moved within the RMI and those who migrated internationally and then returned. The table shows that non-migration and international migration were most common among respondents in Majuro. In the two outer islands, there were more respondents who had moved within the borders of the RMI. Comparing Mejit and Maloelap, migration propensities - including international migration — were higher among respondents in Mejit.

Most of the 79 respondents in the destination areas in the USA were born in the Marshall Islands (100\% in Hawaii and $87 \%$ in the Pacific Northwest) and of those born in the RMI, $70 \%$ primarily came from the urban atolls Majuro and Ebeye. A majority speak English (75\% in Hawaii and $62 \%$ in the Pacific Northwest). The average number of years they had stayed in the USA was 15 years in the case of Hawaii and 12 years for respondents in the Pacific Northwest. Approximately half the respondents in the USA were women (51.9\%).

\subsection{Impact of climatic events}

The questionnaire asked respondents whether their households had been affected by any climatic events in the past 5 years. A clear finding, shown in Table 2, was that many more households indicated that they had been affected by drought (92\%) and heatwaves (47\%) than by king tides (37\%), storm surges (14\%) and typhoons (5\%).

The questionnaire also inquired about changes in the severity of these events over the past 10-20 years. Across the three study sites, a vast majority perceived that the severity of drought had increased $(86.8 \%)$ and that the severity of typhoons $(86.1 \%)$ and storm surges $(79.5 \%)$ had remained the same. Approximately half the respondents perceived that heatwaves $(48.9 \%)$ and king tides $(55.1 \%)$ had increased.

When asked how these natural hazards affected households, the most common impacts respondents mentioned were - in decreasing order of number of affected households - adverse effects on drinking water, trees, land, crops, livestock, health, properties, houses and fish (see Fig. 3). On Mejit, respondents reported the highest number of impacts (5.18 on average), followed by Maloelap (4.60) and Majuro (3.54).

The questionnaire included an open-ended question about how respondents' households were affected by different climatic events. The information from this question gave more detail about event-specific impacts on people's lives and livelihoods. Key insights are listed below:

- During droughts, household members become dehydrated and sick because they do not drink enough or because they drink well water that is too salty.

- In times of drought, respondents spend more money on buying drinking water.

Table 2 Proportion of population affected by climate-related stressor in the past 5 years

\begin{tabular}{lccrr}
\hline Stressor & Mejit & Maloelap & Majuro & Total \\
\hline Drought & $96 \%$ & $94 \%$ & $88 \%$ & $92 \%$ \\
Heatwave & $82 \%$ & $40 \%$ & $33 \%$ & $47 \%$ \\
King tide & $36 \%$ & $44 \%$ & $35 \%$ & $37 \%$ \\
Storm surge & $22 \%$ & $8 \%$ & $13 \%$ & $14 \%$ \\
Typhoon & $6 \%$ & $8 \%$ & $3 \%$ & $5 \%$ \\
\hline
\end{tabular}




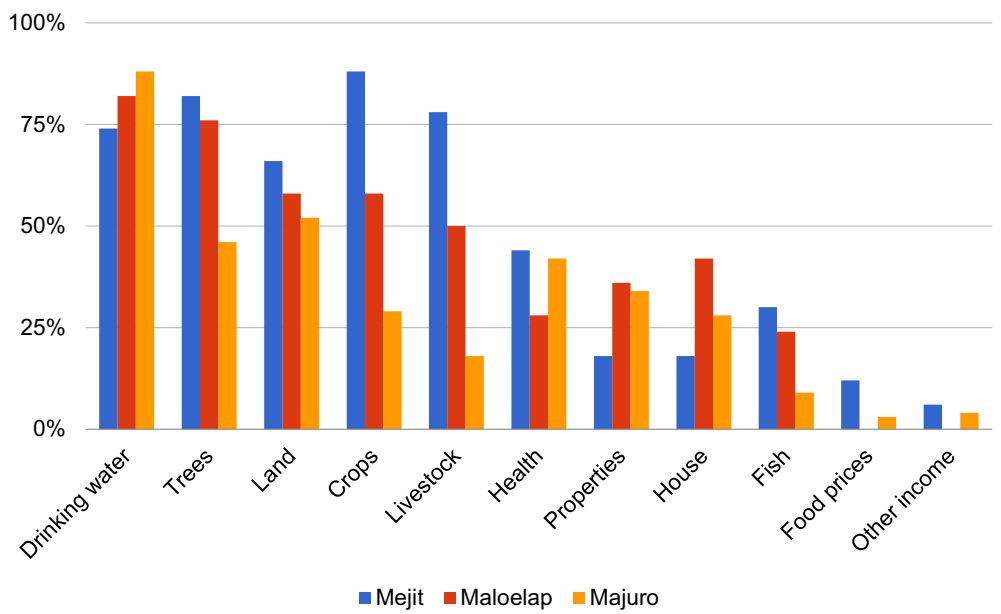

Fig. 3 Impacts of climate-related stressors in the past 5 years (percentage of households affected)

- Some people have to beg for water when their reserves are down, if they lack money to buy water. One respondent said: "We go to other people's houses during droughts and ask if they can give us water which is a very shameful thing to do." (R-82, Majuro)

- During droughts, people need to walk far to find potable drinking water.

- In times of drought, there is more dust, which affects health, especially of children

- During heatwaves, animals die and fishes move further away from the islands.

- Plants do not grow well and some die in times of drought and heat.

- Trees do not produce much fruit in dry times and some die.

- King tide and storms cause damage to houses, properties, trees, crops and seawalls.

\subsection{Ecosystem services}

The survey in the Marshall Islands also assessed people's views on the current state and trends of ecosystem services. The Millennium Ecosystem Assessment (MEA (Millennium Ecosystem Assessment) 2005) distinguishes four broad categories of ecosystem services: provisioning, supporting, regulating and cultural. However, these categories are too abstract to ask directly to respondents. Therefore the questionnaire inquired about more tangible ecosystem services that were relevant to people in the study sites: ecosystem provisioning of food, freshwater and fuelwood, and protection against storms and flooding. Table 3 summarizes the results.

Most respondents perceive that the ecosystem on their island is still able to provide food, water, fuelwood and protection, but not enough, and more than a third perceived a negative trend in ecosystem services provision, particularly in the case of food and water provision (see Table 3).

Respondents on Majuro were most negative about the state of their ecosystem, especially in terms of its ability to provide food and fuelwood. However, the trends they perceive are not as negative as for the two other sites, probably because ecosystem services already deteriorated severely some decades ago. Due to high population density and urbanization, people depend less on these services and have non-ecosystem-based alternatives (imported food available in 
Table 3 Current state and 10-year trend of four ecosystem services by island

\begin{tabular}{|c|c|c|c|c|c|c|c|c|c|}
\hline \multicolumn{5}{|c|}{ Provisioning of food $(\%)$} & \multicolumn{5}{|c|}{ Provisioning of fuelwood $(\%)$} \\
\hline Current State & Mejit & Maloelap & Majuro & Total & Current State & Mejit & Maloelap & Majuro & Total \\
\hline Providing enough & 2.0 & 14.0 & 4.0 & 6.6 & Providing enough & 54.0 & 86.0 & 8.3 & 39.8 \\
\hline Not enough & 94.0 & 82.0 & 63.9 & 76.1 & Not enough & 44.0 & 14.0 & 38.5 & 33.7 \\
\hline Hardly providing & 4.0 & 4.0 & 30.9 & 17.3 & Hardly providing & 2.0 & 0.0 & 53.1 & 26.5 \\
\hline 10 -year trend & & & & & 10 -year trend & & & & \\
\hline Improved & 0.0 & 2.1 & 8.6 & 4.7 & Improved & 22.4 & 52.1 & 3.3 & 20.6 \\
\hline Stayed the same & 34.7 & 54.2 & 61.3 & 52.6 & Stayed the same & 69.4 & 35.4 & 31.5 & 42.3 \\
\hline Deteriorated & 65.3 & 43.8 & 30.1 & 42.6 & Deteriorated & 8.2 & 12.5 & 65.2 & 37.0 \\
\hline \multicolumn{5}{|c|}{ Provisioning of water $(\%)$} & \multicolumn{5}{|c|}{ Protection against floods and storms (\%) } \\
\hline Current State & Mejit & Maloelap & Majuro & Total & Current State & Mejit & Maloelap & Majuro & Total \\
\hline Providing enough & 6.1 & 8.5 & 21.5 & 14.3 & Providing enough & 4.1 & 24.5 & 9.4 & 11.9 \\
\hline Not enough & 67.3 & 66.0 & 59.1 & 63.0 & Not enough & 85.7 & 61.2 & 79.2 & 76.3 \\
\hline Hardly providing & 26.5 & 25.5 & 19.4 & 22.8 & Hardly providing & 10.2 & 14.3 & 11.5 & 11.9 \\
\hline 10 -year trend & & & & & 10 -year trend & & & & \\
\hline Improved & 4.2 & 10.6 & 13.0 & 10.2 & Improved & 2.1 & 6.3 & 10.9 & 7.4 \\
\hline Stayed the same & 22.9 & 38.3 & 54.3 & 42.2 & Stayed the same & 70.8 & 68.8 & 63.0 & 66.5 \\
\hline Deteriorated & 72.9 & 51.1 & 32.6 & 47.6 & Deteriorated & 27.1 & 25.0 & 26.1 & 26.1 \\
\hline
\end{tabular}

shops, gas stoves, tap water and sea walls or embankments). This is different for respondents on Mejit and Maloelap whose livelihoods and protection are still quite dependent on the natural resource base. People on Mejit perceived the most negative trends in ecosystem services, especially for food and water provision. On Maloelap, respondents were slightly less negative than on Mejit about trends in ecosystem services.

When respondents indicated that ecosystem services had deteriorated, the questionnaire inquired - in an open-ended question - about their views on the causes of the changes. Below, the changes for each of the four ecosystem services are summarized.

Food Most respondents pinpointed drought, heatwaves, salinity and changing seasons as the causes of reduced food provisioning by the local ecosystem. These factors affect the productivity of soil and trees. A few respondents mentioned other causes, particularly the lack of space for farms and trees due to urbanization.

Fuelwood Respondents mentioned two reasons for reduced availability of fuelwood. Firstly, they noted that trees had died due to drought and salinity. Secondly, they pointed to population pressure, with too many people depending on trees for fuelwood.

Freshwater In respondents' view, the deterioration of ecosystem provisioning of freshwater was due to drought. Some added that there was not enough storage capacity and a few mentioned increased salinity, which makes the water less suitable and less healthy for consumption.

Protection against floods and storms The loss of trees played a central role in people's views on the reduced ability of the ecosystem to protect people against storms and floods. They added that trees along the coast were affected by king tides, bigger waves, heat, storm surges and saltwater intrusion. As other reasons for the reduction in protection against floods 
and storms, respondents mentioned coastal erosion and degradation of coral and the reef platform due to ocean heating and damage caused by people.

\subsection{Migration patterns}

In the questionnaire, the research team asked respondents about the place of residence of all their siblings and children. This made it possible to calculate domestic and international migration rates for each of the respondents' families. For migrant relatives, additional migration data was gathered, such as destination, purpose, occupation, year of departure and duration.

The survey findings about migrant relatives (Table 4) confirm the high migration propensities of the Marshallese as shown in recent RMI and US census reports. A vast majority of respondents $(91.5 \%)$ had at least one brother, sister, son or daughter who had migrated and $68.7 \%$ had siblings or children who lived abroad, mostly in the USA. The average number of migrant siblings and children per respondent was 3.1. Out of these migrant relatives, about half (49.4\%) lived elsewhere in the RMI and the rest had migrated internationally. A gender breakdown of migrant relatives shows that $55.8 \%$ were men and $44.2 \%$ were women. Among those who moved to the USA, the gender distribution was similar: $57.4 \%$ were men and $42.5 \%$ were women. Arkansas, Hawaii and the state of Washington were the most frequent international destinations for the siblings and children of survey respondents.

The survey results about migrant relatives revealed significant differences between the three study sites. The outer island of Mejit has the highest out-migration rate. More than half the siblings and children of questionnaire respondents (54.4\%) had moved, while in the other two study sites, about a third had migrated. Another significant difference between study sites is that less than $40 \%$ of the migrant relatives of respondents on Mejit and Maloelap migrated internationally while most migration from Majuro (65.7\%) was international.

In the questionnaire, the research team also asked respondents whether they thought that they or any of their household members would migrate within the RMI or abroad in the next 10 years. In more than half the household (53.3\%), at least one member was considering to migrate. On Mejit and Maloelap, about two-thirds of this group intended to migrate within the RMI, mostly to Majuro. The rest intended to move to the USA. Almost all respondents in Majuro who intended to migrate in the next 10 years mentioned that they wanted to move to the USA.

\subsection{Migration drivers}

The sections in the questionnaire that focused on migration each inquired about the reasons for past, present and future moves. In each section, we used the same categories of migration

Table 4 Proportion of domestic and international migrants among siblings and children

\begin{tabular}{lllll}
\hline & Mejit & Maloelap & Majuro Total \\
\hline Migrant siblings and children (percentage of all living siblings + children) & $54.4 \%$ & $33.6 \%$ & $33.8 \%$ & $39.4 \%$ \\
Siblings and children who migrated internationally (mainly USA) & $21.6 \%$ & $11.6 \%$ & $22.2 \%$ & $19.0 \%$ \\
Proportion of migrants moving internationally & $39.7 \%$ & $34.6 \%$ & $65.7 \%$ & $48.3 \%$ \\
\hline
\end{tabular}




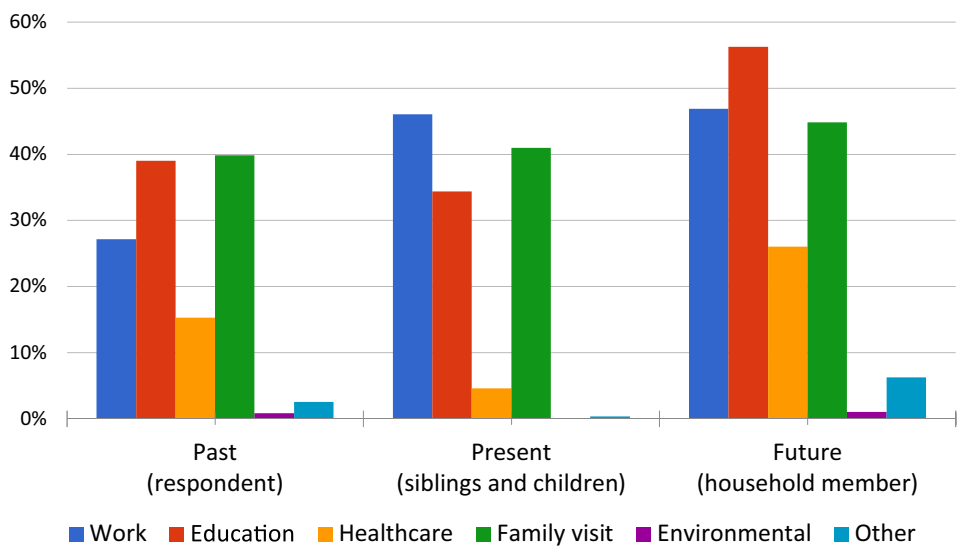

Fig. 4 Proportion of migrants moving because of different drivers in the past, present and future

drivers: work, education, health care, visiting relatives, environmental drivers and other. Figure 4 shows how frequently different reasons were offered for each migration type.

The graph shows that work, education and family visits are the most common reasons for migration, each being a factor in approximately $40 \%$ of the moves. Migration to seek health care is also common but tends to be of shorter duration, which explains the lower number of current migrants who moved for medical reasons.

Of particular relevance to this paper is the very low number of respondents who mentioned environmental reasons for migration. While respondents expressed concern about the future impacts of climate change on their islands, the survey findings show that they do not yet identify these impacts as important drivers of migration.

The insights from the focus group discussions are largely in line with these findings. According to the participants, the reasons why people migrate include poor education, poor health care, limited income generation opportunities and adventure seeking. Participants further stated that climate change and sea level rise are not yet common reasons for which people migrate but rather something that might spur migration in the future.

During the focus group discussions, for each migration driver, the facilitators asked about underlying causes.

Poor education and health care According to focus group participants, the main reason behind people's decision to migrate for education or health care is the low level of education and health care on their island. Underlying the poor education and health care are the logistical difficulties of infrequent inter-island transportation that makes it harder to provide sufficient resources for a good education, such as materials and qualified teachers.

Work The main reason why people migrate for work is that there are limited opportunities for generating income. This is particularly the case on the outer islands, but also applies to Majuro. An important underlying reason is what the participants called a deterioration of the island's productivity. The reasons behind the decline in island productivity, they indicated, are both natural and human. These include increasing soil salinity, more frequent drought and heatwaves, invasive species and pests and controlled fires (to clear unwanted organic material 
and other waste) that turn into wildfires. Lastly, they mentioned that out-migration contributes to a decreasing availability of labour to cultivate the land, which reduces island productivity.

Seeking adventure The last reason for migration that participants mentioned was 'seeking adventure' and a desire to see and experience the world beyond one's island. An underlying cause of this desire is the curiosity that is fed by increased access and exposure to the 'popular culture' of the USA through TV and the internet.

Besides migration drivers, the participants also identified enablers or facilitators of migration. These are things that make it easier to migrate from their island. As an example, participants mentioned the tax refund in the USA that enables migrants to buy tickets for their relatives at home. Another enabler is that no visa is needed for entry and work in the USA. Lastly, focus group participants mentioned the fact that almost all islanders have relatives and friends in the USA with whom they can stay.

\subsubsection{Findings from migrant destination areas in the USA}

Respondents in Hawaii and the Pacific Northwest were also asked why they had decided to come to the USA. They were able to select multiple migration rationales. On average, education $(72.2 \%)$, health care $(58.2 \%)$, economic opportunities $(51.9 \%)$ and familial networks $(63.3 \%)$ were the most frequently selected (see Table 5). In both destination areas, environmental factors were mentioned less frequently as migration rationales. In the Pacific Northwest, only 1 respondent mentioned environmental drivers, a pattern similar to the findings in the RMI. However, a substantial proportion of respondents in Hawaii indicated that poor environmental conditions (32.5\%), environmental disasters $(25.0 \%)$ or the threat of sea level (30\%) influenced their migration decision.

The questionnaire also inquired whether environmental factors, such as sea level rise and freshwater availability, played a role in respondents' decision to return to the Marshall Islands someday. In Hawaii, this was the case for $65.0 \%$ of respondents and $59.0 \%$ in the Pacific Northwest.

Findings from Hawaii and the Pacific Northwest are similar to a recent study conducted among Marshallese migrants in Springdale, Arkansas (McClain et al. 2019: 9). The authors write: 'While climate change was never the sole reason provided for relocation to Springdale, many $(35 \%)$ indicated it was a concern and that it compounded their desire to emigrate to the U.S. An even more sizable percentage (45\%) indicated they did not intend to return to RMI permanently due to climate change factors'.

Table 5 Migration rationales mentioned by respondents in the USA

\begin{tabular}{llll}
\hline & Hawaii $(N=40)$ & Pacific NW $(N=39)$ & Total $(N=79)$ \\
\hline Better education and schools than the RMI & $80.0 \%$ & $64.1 \%$ & $72.2 \%$ \\
Spouse and familial network & $70.0 \%$ & $56.4 \%$ & $63.3 \%$ \\
Better health care than in the RMI & $72.5 \%$ & $43.6 \%$ & $58.2 \%$ \\
Better economic opportunity and living conditions & $70.0 \%$ & $33.3 \%$ & $51.9 \%$ \\
Poor environmental conditions in the RMI & $32.5 \%$ & $2.6 \%$ & $17.7 \%$ \\
Threat of sea level rise & $30.0 \%$ & $2.6 \%$ & $16.5 \%$ \\
Environmental disasters in the RMI & $25.0 \%$ & $2.6 \%$ & $13.9 \%$ \\
\hline
\end{tabular}


Table 6 Household-level correlations between migration rates and perceptions of climate impacts and ecosystem services

\begin{tabular}{|c|c|c|c|c|}
\hline $\begin{array}{l}\text { Affected in past } 5 \text { years } \\
(0=\text { no; } 1=\text { yes })\end{array}$ & $\begin{array}{l}\% \text { migrant } \\
\text { relatives }\end{array}$ & $\begin{array}{l}\text { \% migrant } \\
\text { relatives in } \\
\text { the U.S. }\end{array}$ & $\begin{array}{l}\text { Intention to } \\
\text { migrate } \\
\text { (0=no; } \\
\text { 1=maybe; } \\
\text { 2=yes) }\end{array}$ & $\begin{array}{c}\text { Intention to } \\
\text { migrate to the } \\
\text { U.S. } \\
\text { (0=no; } 1=\text { maybe; } \\
\text { 2=yes) }\end{array}$ \\
\hline Drought & $X$ & $X$ & $X$ & $X$ \\
\hline Heat wave & Positive $(* *)$ & Positive $(* *)$ & $X$ & $X$ \\
\hline Typhoon & $x$ & $x$ & $x$ & $x$ \\
\hline King tide & $X$ & $X$ & $\mathrm{X}$ & $x$ \\
\hline Storm surge & Positive $\left({ }^{*}\right)$ & Positive $\left({ }^{*}\right)$ & $\mathrm{X}$ & $x$ \\
\hline Sum of impact types & Positive $(*)$ & Positive $(*)$ & Positive $(*)$ & $x$ \\
\hline \multicolumn{5}{|l|}{$\begin{array}{l}\text { Trend in past } 10-20 \text { years } \\
0=\text { did not increase; } \\
1=\text { increased }\end{array}$} \\
\hline Drought & $x$ & $X$ & $X$ & $x$ \\
\hline Heat wave & Positive $(* *)$ & Positive $\left({ }^{*}\right)$ & $x$ & $x$ \\
\hline Typhoon & $x$ & $x$ & $x$ & $x$ \\
\hline King tide & Negative $(*)$ & $x$ & $x$ & $x$ \\
\hline Storm surge & Positive $\left({ }^{* *}\right)$ & Positive $\left({ }^{* *}\right)$ & $\mathrm{X}$ & $x$ \\
\hline \multicolumn{5}{|l|}{$\begin{array}{l}\text { State of ESS } \\
\text { 1=providing enough; } \\
\text { 2= not providing enough' } \\
\text { 3=hardly providing }\end{array}$} \\
\hline Food & $x$ & $x$ & $x$ & $x$ \\
\hline Fuel wood & Negative $(*)$ & $x$ & $x$ & Positive $(* *)$ \\
\hline Water & $\mathrm{X}$ & $\mathrm{X}$ & $\mathrm{X}$ & $\mathrm{X}$ \\
\hline Protection & $x$ & $x$ & $x$ & $x$ \\
\hline \multicolumn{5}{|l|}{$\begin{array}{l}\text { Trend in ESS } \\
\text { 1=improved; } \\
\text { 2=stayed the same; } \\
\text { 3=deteriorated }\end{array}$} \\
\hline Food & $X$ & $X$ & Positive $(*)$ & $x$ \\
\hline Fuel wood & $x$ & $x$ & $x$ & Positive $(* *)$ \\
\hline Water & Positive $\left({ }^{*}\right)$ & $X$ & $X$ & Negative $(* *)$ \\
\hline Protection & $x$ & $x$ & Positive $\left({ }^{*}\right)$ & $x$ \\
\hline
\end{tabular}

\subsection{Linking climate change, ecosystem services and migration}

This section reviews the evidence concerning possible linkages between the set of variables related to climate impacts and ecosystem services and those related to migration. Based mostly on the questionnaire, the paper thus far presented descriptive statistics of people's perceptions and experiences with climate impacts and ecosystem services, and their migration behaviour in the past, present and future. The current section moves from descriptive statistics to a more analytical approach, exploring how climate impacts, ecosystem services and migration are related. This analysis contributes to answering the central question: To what extent are climatic stressors and their impacts on ecosystems, livelihoods and habitability, driving migration in the Marshall Islands? 
The analysis relates a range of climate impact and ecosystem service variables to four migration variables (see Table 6). The four migration variables have two dimensions: time and space. The time dimension distinguishes current and future migration. In the spatial dimension, a distinction is made between all migration and international migration only. The four resulting migration variables are:

1. The percentage of respondents' siblings and children who reside elsewhere (not on the island of enumeration);

2. The percentage of siblings and children who reside abroad;

3. Household members' intention to migrate in the next 10 years;

4. Household members' intention to migrate abroad in the next 10 years.

We relate the migration variables to climate impact and ecosystem service variables. The climate impact variables are:

- Whether the respondent's household has been affected by droughts, heatwaves, typhoons, king tides and storm surges in the past 5 years;

- Perceived trends in these climatic events over the past 10-20 years.

The ecosystem service variables are:

- Perceived state of ecosystem services (food, fuelwood, water, protection)

- Perceived trends in these ecosystem services

In Table 6, a cell is shaded green when the statistical relationship between two variables is in support of the hypothesis that climate impacts and environmental problems drive migration. By contrast, grey-shaded cells show statistically significant relations between a migration and a climate impact or environmental variable that are not in support of the hypothesis. When cells contain an ' $\mathrm{X}$ ' symbol, it means that there is no statistically significant correlation $(p>0.05)$ between the two variables.

Significant positive correlations are found between impacts of heatwaves $(p<0.01)$ and storm surges $(p<0.05)$ and current migration. Respondents who reported impacts of heatwaves and storm surges (such as health impacts, agricultural losses or damage to properties) in the past 5 years have a higher proportion of children and siblings who have moved away from the island including to the USA. Heatwave and storm surge trends also correlate positively with the proportion of migrant relatives. Respondents who perceive that the frequency and severity of heatwaves and storm surges have increased tend to have a higher proportion of siblings and children who have left the island. These positive correlations indicate that migration propensities tend to be higher in climate-stressed households. Correlation does not necessarily imply causality, however, nor does it say anything about the direction of causality. It is possible that households with more migration experience have greater awareness of climate change and therefore perceive and report more climate impacts on their households. More research is needed to study this. It is important to note the role of the northernmost study site, Mejit. Households on this island reported significantly more climate impacts than in the other two study sites - particularly from heatwaves and storm surges - and also had the highest migration rates (see 'Impact of climatic events' and 'Migration patterns'). 
Table 6 also shows that the number of positive correlations between climate impact variables is similar for general migration variables and for international migration variables. Much fewer correlations were found between climate impact variables and the intention of household members to migrate in the next 10 years.

The relationship between migration and ecosystem services is also examined in Table 6 . The table shows several significant relations, particularly between migration intentions and perceived trends in the ecosystem services of food provision, fuel wood provision and protection against storms and floods. Household members of respondents who perceive that these ecosystem services are deteriorating are more likely to intend to migrate in the next 10 years. However, in most cells, no significant correlation is found, and in two cases, the correlation is negative. 'Ecosystem services' showed that the ecosystems in the three study sites are under pressure. There is some indication that people who perceive negative trends in ecosystem services are more likely to migrate in the future.

\subsection{Spatial analysis}

The analysis linking climate impacts, ecosystem system services and migration in this paper has thus far relied on perception data and self-reporting of respondents. To triangulate the results, geospatial flood extent data were used to explore whether households in recently flooded areas are more inclined to migrate. Figure 5 shows, in blue lines, the areas in two of our study sites that have been inundated in the past years, specifically March 2014 in Majuro
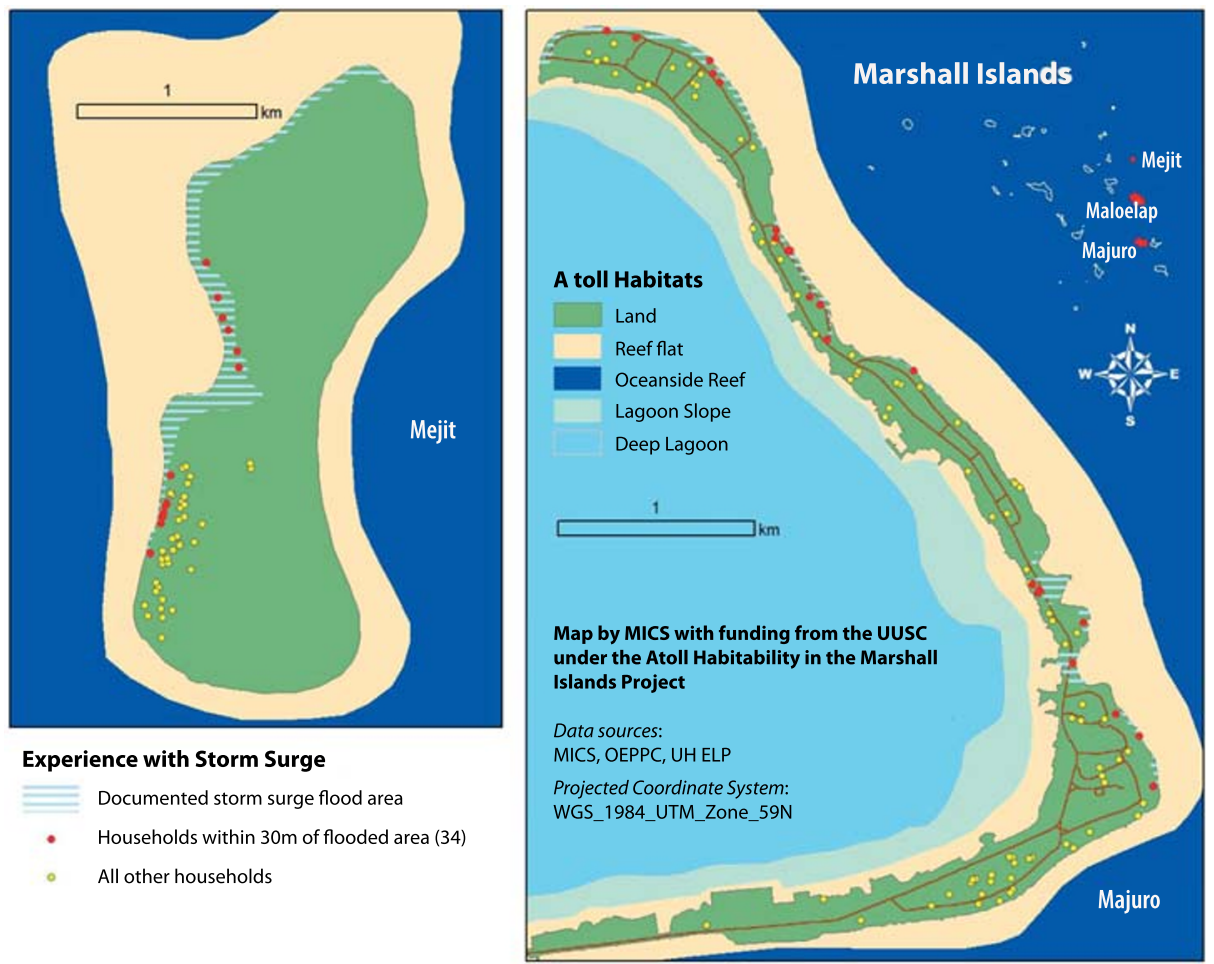

Fig. 5 Flood extent on Majuro (2014) and Mejit (2015) 
Table 7 Migration propensities of households in flooded and non-flooded areas

\begin{tabular}{llll}
\hline & In flood area & Not in flood area & Total \\
\hline Percentage of migrant relatives & $44.4 \%$ & $40.2 \%$ & $41.2 \%$ \\
Percentage of migrant relatives in the USA & $24.7 \%$ & $23.5 \%$ & $23.8 \%$ \\
Household member intends to migrate within 10 years (\%) & $55.9 \%$ & $57.4 \%$ & $57.0 \%$ \\
Household member intends to migrate to the USA within 10 years (\%) & $33.3 \%$ & $40.6 \%$ & $38.9 \%$ \\
\hline
\end{tabular}

None of the differences between households within and outside the flood zones are significant at $p<0.05$ level

and January 2015 in Mejit. The flood extent data was based on participatory mapping that leveraged photographic documentation and experiential knowledge by flood extent witnesses (Stege 2018). In total, 34 households (21 on Majuro and 13 on Mejit) within our survey sample were flooded or within 30-m distance of observed flood areas. On the map, these households are represented with a red dot. The other households have yellow dots.

Table 7 compares current and future migration propensities between households inside and outside the flood zones. 'Current migration' is expressed as the percentage of siblings and children who are currently internal or international migrants. 'Future migration' is expressed as the percentage of households of whom at least one member intends to migrate in the next 10 years.

The differences in migration propensities between households within and outside the flooded areas on Majuro and Mejit are small and not statistically significant. This is the case for current and future migration and for internal and international migration. The findings from this spatial analysis provide no indication that flood impacts drive migration within or from the Marshall Islands.

\section{Discussion and conclusions}

Respondents perceive that the main drivers of migration in and from the RMI are related to education, health care, work and family networks. Less than $1 \%$ of respondents in the RMI cite climate impacts or environmental change as drivers of migration. This was the case for past migrations (of the respondents), current migrations (of siblings and children) and future migrations (of household members). In destination areas in the Pacific Northwest of the USA, the Marshallese migrants we interviewed also did not attribute their migration decision to environmental problems. However, in Hawaii, a much higher proportion of respondents stated that environmental problems $(32.5 \%)$ and sea level rise $(30.0 \%)$ had influenced their decision to migrate to the USA.

Arguably, simply asking respondents why they migrated does not provide a full and reliable picture of migration drivers (Bilsborrow and Henry 2012). In the case of Marshallese migration, the dominant discourse is that people migrate for work, education and health care, and this may be replicated in the answers (see e.g. Graham 2008). In a questionnaire interview setting, respondents may prefer to give the 'expected answer' even though they know that the reality is more complex. This study sought to provide a more complete picture of environmental and other drivers of migration by triangulating the findings on cited reasons to migrate with (1) participatory research methods to study the underlying causes of migration; (2) a statistical analysis of correlations between perceptions of climate impacts, ecosystem services and migration propensities; and (3) a spatial analysis of flood extent and migration rates. The findings confirm that education, health care, work and family networks are prime drivers of Marshallese migration, but a more nuanced picture emerges for climatic events and other environmental drivers of migration. 
The analysis of correlations between climate impacts and migration, for example, shows that households of respondents who report heatwave and storm surge impacts and perceive that these climatic events are worsening have higher migration propensities. Similarly, household members of respondents who perceive negative trends in ecosystem services are more likely to intend to migrate within the next 10 years. These findings were presented and discussed in an information sharing workshop with policymakers and community representatives in Majuro in July 2018. There was consensus among participants that particularly heatwaves can trigger migration decisions. They specified that people are more likely to make the final decision to migrate after a prolonged period of heat even though the migration decision is also motivated by other factors.

Another interesting finding of this research is that almost two-thirds (62.0\%) of Marshallese respondents in the USA stated that environmental factors, such as sea level rise and freshwater availability, affect their decision to return to Marshall Islands someday. So while a majority did not cite environmental problems as an important reason to move to the USA, they do fear that their islands could become less suitable or attractive for habitation in the future.

An important limitation of this research is that the research team could only survey three study sites while the RMI consists of 29 coral atolls and 5 raised coral islands. In the info sharing event in Majuro, policymakers and community representatives emphasised that this research should be considered a baseline for future research and that similar studies need to be conducted every 5-10 years and covering more islands.

Acknowledgements The authors wish to thank the following persons for their contributions in various stages of the research: David Helweg, Shunya Ku'ulei Arakaki, Dana Lum, Heather Kerkering, Victoria Keener, John Marra, Laura Brewington, Zena Grecni, Kristen Oleson, Chip Fletcher, Mickael de Souza, Miquel Colom, Robert Oakes, Ben Graham, Kevin Morris, Joseph Mook Jr., Joel Bujen, Paul Lainej, Dilia Mares, Newton Lajuan, Martha Horiuchi-Henry, Dina Shek, Natalie Nimmer, Joanne Loeak, Emi Chutaro, Tamara Heine, David Anitok and Loyd Henion. Finally, the authors wish to extend their deepest gratitude to the respondents in the Republic of the Marshall Islands and in the United States who took the time to answer our many questions during the survey interviews, group discussions and informal conversations.

Funding information Open Access funding provided by Projekt DEAL. This research was funded by the Pacific Island Climate Adaptation Science Center and the Pacific Research and Integrated Science Assessments Program. Complimentary funding to support spatial analysis was provided by the Unitarian Universalist Service Committee (UUSC).

Open Access This article is licensed under a Creative Commons Attribution 4.0 International License, which permits use, sharing, adaptation, distribution and reproduction in any medium or format, as long as you give appropriate credit to the original author(s) and the source, provide a link to the Creative Commons licence, and indicate if changes were made. The images or other third party material in this article are included in the article's Creative Commons licence, unless indicated otherwise in a credit line to the material. If material is not included in the article's Creative Commons licence and your intended use is not permitted by statutory regulation or exceeds the permitted use, you will need to obtain permission directly from the copyright holder. To view a copy of this licence, visit http://creativecommons.org/licenses/by/4.0/.

\section{References}

Afifi T et al (2016) Human mobility in response to rainfall variability: opportunities for migration as a successful adaptation strategy in eight case studies. Migr Dev 5(2):254-274

Allgood L, McNamara K (2017) Climate-induced migration: exploring local perspectives in Kiribati. Singap J Trop Geogr 38(3):370-385

Barnett J (2017) The dilemmas of normalising losses from climate change: towards hope for Pacific atoll countries. Asia Pac Viewp 58(1):3-13

Bilsborrow R, Henry S (2012) The use of survey data to study migration-environment relationships in developing countries: alternative approaches to data collection. Popul Environ 34(1):113-141

Black R et al (2011) The effect of environmental change on human migration. Glob Environ Chang 21:S3-S11 
Bureau Of East Asian And Pacific Affairs (2015) Factsheet: U.S. relations with the Marshall Islands. Available at http://www.state.gov/r/pa/ei/bgn/26551.htm. Accessed 21 November 2019

Campbell J, Oakes R, Milan A (2016) Nauru: climate change and migration: relationships between household vulnerability, human mobility and climate change. UNU-EHS, Bonn

Connell J (2005) A nation in decline? Migration and emigration from the Cook Islands. Asian Pac Migr J 14(3): $327-350$

Davis D (2014) Modeling scenarios of sea-level rise and human migration: Rita Village, the Republic of the Marshall Islands. Dissertation, University of Arkansas

Eklund L, Romankiewicz C, Brandt M, Doevenspeck M, Samimi C (2016) Data and methods in the environment-migration nexus: a scale perspective. DIE ERDE 147(2):139-152

Foresight (2011) Migration and global environmental change: future challenges and opportunities. Final Project Report. The Government Office of Science, London

Graham B (2008) Determinants and dynamics of Micronesian emigration. Background paper to the Micronesian voices in Hawttaii conference, April 2008

Keener VW et al (2012) Climate change and pacific islands: indicators and impacts. Report for the 2012 Pacific Islands Regional Climate Assessment (PIRCA). Island Press, Washington, DC

Kench PS, Ford MR, Owen SD (2018) Patterns of island change and persistence offer alternate adaptation pathways for atoll nations. Nat Commun 9(1):605

Marra JJ, et al (2017) State of environmental conditions in Hawaii and the U.S. affiliated Pacific Islands under a changing climate: 2017 . NOAA NCEI

McClain SN et al (2019) Migration with dignity: a case study on the livelihood transition of Marshallese to Springdale, Arkansas. J Int Migr Integr. https://doi.org/10.1007/s12134-019-00688-7

McElfish PA (2016) Marshallese COFA migrants in Arkansas. J Ark Med Soc 112(13):259

McLeman R, Smit B (2006) Migration as an adaptation to climate change. Clim Chang 76(1-2):31-53

MEA (Millennium Ecosystem Assessment) (2005) Ecosystems and human well-being: current state and trends. Island Press, Washington DC

Milan A (2016) Rural livelihoods, location and vulnerable environments: approaches to migration in mountain areas of Latin America. Dissertation, University of Maastricht

Milan A, Oakes R, Campbell J (2016) Tuvalu: climate change and migration: relationships between household vulnerability, human mobility and climate change. UNU-EHS, Bonn

Morris K, Burkett M, Wheeler B (2019) Climate-induced migration and the compact of free association (COFA): limitations and opportunities for the citizens of the Republic of the Marshall Islands. Policy Brief of the Marshall Islands Climate and Migration Project. University of Hawaii at Mānoa

Mortreux C, Barnett J (2009) Climate change, migration and adaptation in Funafuti, Tuvalu. Glob Environ Chang 19(1):105-112

Nurse LA et al (2014) Small islands. In: Barros V et al (eds) Climate change 2014: impacts, adaptation, and vulnerability. Cambridge University Press, Cambridge, pp 1613-1654

Oakes R (2019) A subjective understanding of climate change and mobility in Pacific SIDS. Popul Environ 40(4):480-503

Oakes R, Milan A, Campbell J (2016) Kiribati: climate change and migration: relationships between household vulnerability, human mobility and climate change. UNU-EHS, Bonn

Oakes R, Banerjee S, Warner K (2019) Human mobility and adaptation to environmental change. In: World migration report 2020. Geneva: IOM. URL: http://www.iom.int/wmr/2020/chapter/09

Owen SD, Kench PS, Ford M (2016) Improving understanding of the spatial dimensions of biophysical change in atoll island countries and implications for island communities: a Marshall Islands' case study. Appl Geogr 72:55-64

Perumal N (2018) "The place where I live is where I belong": community perspectives on climate change and climate-related migration in the Pacific Island nation of Vanuatu. Isl Stud J 13(1):45-64

Piguet E (2010) Linking climate change, environmental degradation, and migration: a methodological overview. Wiley Interdiscip Rev Clim Chang 1(4):517-524

Republic of the Marshall Islands (2012) 2011 Census Report. Secretariat of the Pacific Community, Noumea

Stege M (2018) Atoll habitability thresholds. In: Leal Filho W, Nalau J (eds) Limits to climate change adaptation. Springer, Cham, pp 381-399

Storlazzi CD et al (2018) Most atolls will be uninhabitable by the mid-21st century because of sea-level rise exacerbating wave-driven flooding. Sci Adv 4(4):eaap9741

US Census Bureau (2001) The native Hawaiian and other Pacific islander population: 2000. United States Census Bureau

US Census Bureau (2012) The native Hawaiian and other Pacific Islander population: 2010. United States Census Bureau 
Van der Geest K, Burkett M, Fitzpatrick J, Stege M, Wheeler B (2019a) Marshallese migration: the role of climate change and ecosystem services. Case study report of the Marshall Islands Climate and Migration Project. University of Hawaii at Mānoa

Van der Geest K, Burkett M, Fitzpatrick J, Stege M, Wheeler B (2019b) Marshallese perspectives on migration in the context of climate change. IOM Policy Brief 5(1):1-12

Van der Land V, Romankiewicz C, van der Geest K (2018) Environmental change and migration: a review of West African case studies. In: McLeman R, Gemenne F (eds) Routledge handbook of environmental displacement and migration. Routledge, London and New York, pp 163-177

Zommers $\mathrm{Z}$ et al (2016) Loss and damage: the role of ecosystem services. UNEP, Nairobi

Publisher's note Springer Nature remains neutral with regard to jurisdictional claims in published maps and institutional affiliations. 